Note

\title{
Influence of Hop Resins on Freeze Injury to Escherichia coli
}

\author{
Tadashi FUKAO ${ }^{1}$ and Yoshiyuki OHTA ${ }^{2}$ \\ ${ }^{1}$ Food Research Laboratories, Nippon Shinyaku Co., Ltd., Nishiohii Hachijo, Minami-ku, Kyoto 601-8550, Japan \\ ${ }^{2}$ Faculty of Applied Biological Science, Hiroshima University, 1-4-4 Kagamiyama, Higashi-Hiroshima 739-8528, Japan
}

Received April 17, 1998; Accepted July, 9, 1998

\begin{abstract}
The influence of hop resins on the freeze-thawing resistance of Escherichia coli K-12 IFO3301 was investigated. When the freeze-thawing treatment of the strain was carried out in nutrient broth containing $0.01 \%$ of hop resins, a great decrease in the viable cell count was observed. Especially, the decrease in the count on the desoxycholate agar plate was remarkable, and no viable cells were found after $24 \mathrm{~h}$ freezing. Further, an extension of the lag phase was observed when the strain after freeze-thawing treatment was incubated in the nutrient broth. Namely, the freeze-thawing injury to the strain was greatly enhanced by the addition of the hop resins. It was thought that the effective utilization of hop resins for hygienic control of frozen foods is feasible.
\end{abstract}

Keywords: hop resins, freeze injury, freeze-thawing treatment, Escherichia coli

The bitter resin components of hop (Humulus luplus L.) have been used for beer brewing since ancient times. Hop resins give beer a flavor and a refreshing bitter taste (Aitken et al., 1970; Kuroiwa et al., 1972; Laws \& McGuinness, 1972; Verzele, 1972) and protect beer from spoilage by bacteria (Brown \& Clubb, 1913; Chapman, 1929; Kleyn \& Hough, 1971; Macrae, 1964; Walker \& Blakebrough, 1952; Walker \& Parker, 1937). With respect to the antimicrobial activity of the resins, many studies have been carried out and have shown a strong antimicrobial activity against Gram positive bacteria but little against Gram negative ones such as Escherichia coli (Chin et al, 1949; Erdmann, 1951; Haas \& Barsoumian, 1994; Hough et al., 1957; Jaehrig \& Schade, 1981; Schmalreck et al., 1975; Shimwell, 1937; Simpson, 1993; Simpson \& Smith, 1992; Smith \& Smith, 1993; Teuber \& Schmalreck, 1973). Some inhibitory activity has also been reported against fungi, but no effect on yeast has been observed (Michener et al., 1948; Mizobuchi \& Sato, 1984; 1985). The authors have been investigating the use of resins for the prevention of food spoilage and food poisoning. Studies show that the presence of hop resins promote freeze injury to $E$. coli during freezethawing treatment and this is reported here.

\section{Materials and Methods}

Test materials and test strain Hop resins were purchased from the Cultor Food Science Co., Ltd., (Milwaukee, Wis.). This product was rich in the $\beta$-acid fraction, which was obtained by removing the $\alpha$-acid (the main bitterness component) from a hop extract using a supercritical carbon dioxide extraction method. Food grade sodium hexametaphosphate (Taiheikagaku Co., Osaka) and glycerine (Wako Pure Chemical Co., Osaka) were also used as test materials. As a test strain, Escherichia coli K-12 IFO3301 (hereinafter referred to as $E$. coli) was used.

Measurement of viable cell count after freeze-thawing treatment The $E$. coli strain was incubated in nutrient broth at $30^{\circ} \mathrm{C}$ for $24 \mathrm{~h}$ and harvested by centrifugation $(10,000 \times g, 15$ $\mathrm{min})$. The cells were washed twice with a sterile $40 \mathrm{mM}$ phosphate buffer ( $\mathrm{pH} \mathrm{6.5)} \mathrm{and} \mathrm{suspended} \mathrm{in} \mathrm{nutrient} \mathrm{broth}$ containing a test material at $10^{7} \mathrm{cfu} / \mathrm{ml}$. This cell suspension $(10 \mathrm{ml})$ in a test tube was frozen at $-20^{\circ} \mathrm{C}$. After one and 8 days, the frozen cell suspension was thawed at room temperature. The change in temperature is shown in Fig. 1 when the freeze-thawing treatment was carried out in nutrient broth. The surviving cells were enumerated by the following methods: 1 . the standard plate count, 2 . the desoxycholate agar count. The standard plate was incubated at $35^{\circ} \mathrm{C}$ for 48 $\mathrm{h}$ and the desoxycholate agar was incubated at $37^{\circ} \mathrm{C}$ for $24 \mathrm{~h}$. These tests were performed by the pour plate method. The final concentrations of hop resins, sodium hexametaphosphate, and glycerine in the nutrient broth were $0.01,1$, and $10 \%$, respectively. These concentrations of test materials have no effect on the growth of E. coli (Haas \& Barsoumian, 1994; Mizobuchi \& Sato, 1984; Schmalreck et al, 1975; Tutumi et al., 1976). Also, it was confirmed by organoleptic evaluation (flavor and taste) that these concentrations had no effect on foods (unpublished).

Measurement of lag time for growth The lag time for the growth of $E$. coli was examined in the nutrient broth medium after freeze-thawing treatment. The inoculum size in the nutrient broth was about $10^{1} \mathrm{cfu} / \mathrm{ml}$. The incubation was carried out with an automatic growth monitoring apparatus (Bioscanner; Ohtakeseisakusho Co., Tokyo), which continuously measured the absorbancy at $650 \mathrm{~nm}$. The period from the start of incubation until the increase in the absorbency at $650 \mathrm{~nm}$ was regarded as the log time for growth.

\section{Results and Discussion}

After the freeze-thawing treatment, the viable cell count of $E$. coli decreased as shown in Fig. 2. With the standard plate count method, the viable cells in the nutrient broth without test materials decreased from $10^{7} \mathrm{cfu} / \mathrm{ml}$ to $10^{4} \mathrm{cfu} / \mathrm{ml}$ after 8 
I

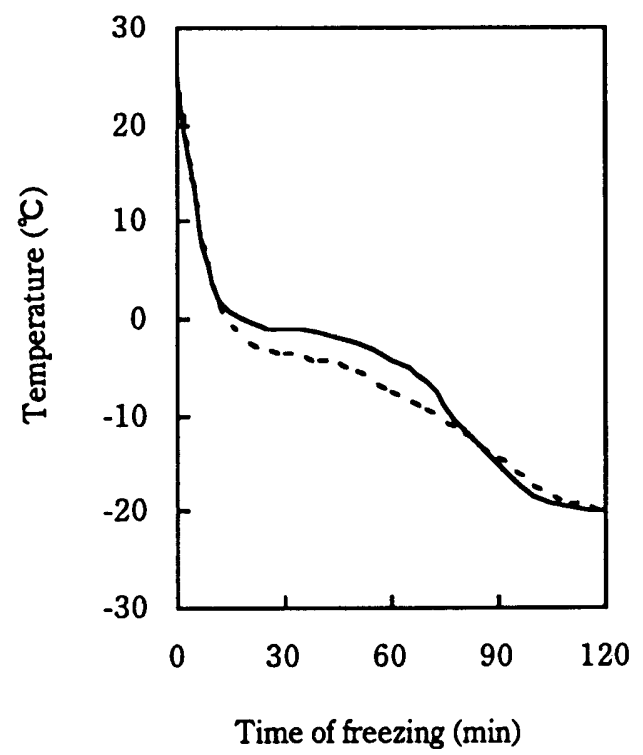

II

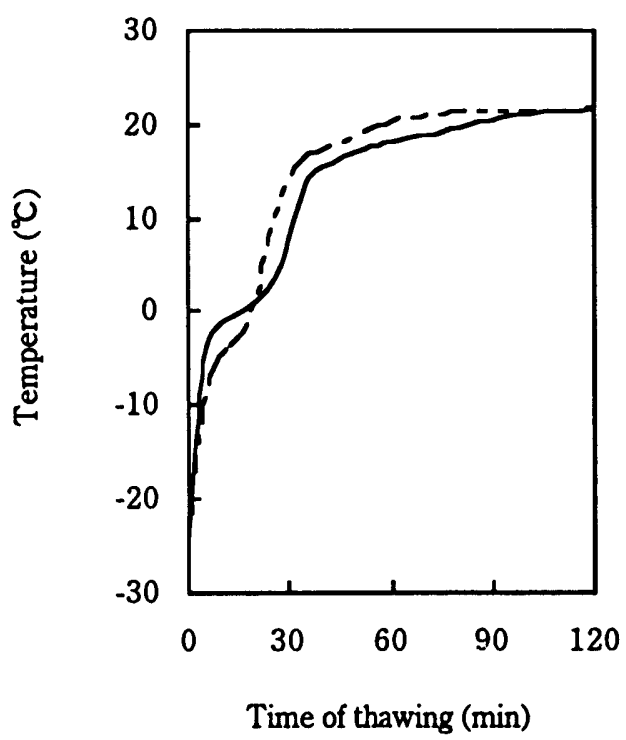

Fig. 1. Change in temperature during the freeze-thawing treatment (I: freezing treatment, II: thawing treatment) in the nutrient broth ( - ) and in the nutrient broth containing glycerin (---).

1

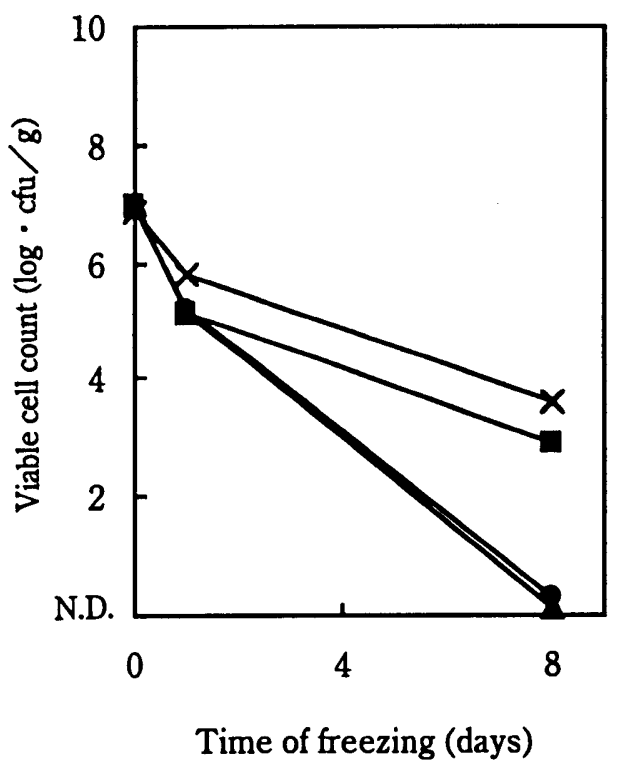

II

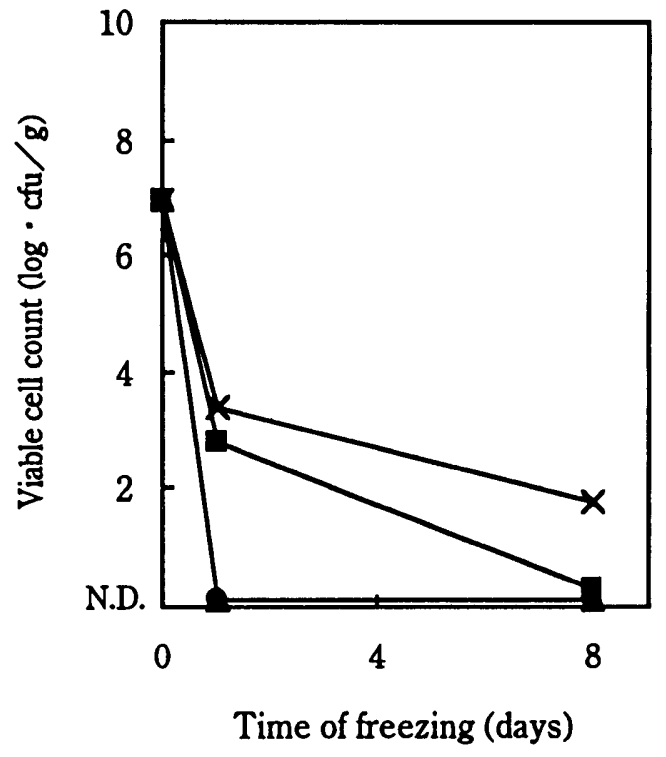

Fig. 2. Viable cell count of $E$. coli after the freeze-thawing treatment in the nutrient broth. The surviving cells were enumerated by the following methods: I. the standard plate count, II. the desoxycholate agar count. Test materials added were as follows. $\times$ : No addition; $\bullet$ : Hop resins; $\mathbf{\square}$ : Sodium hexametaphosphate; $\mathbf{\Delta}$ : Hop resins + Sodium hexametaphosphate.

days of freezing. With the addition of sodium hexametaphosphate, the cell count decreased from $10^{7} \mathrm{cfu} / \mathrm{ml}$ to $10^{3} \mathrm{cfu} / \mathrm{ml}$; whereas, with hop resin, the count decreased to below $30 \mathrm{cfu} /$ $\mathrm{ml}$. It was not possible to form the colony when hop resins and sodium hexametaphosphate were used in combination. On the other hand, with the desoxycholate agar method, the viable cell count decreased from $10^{7} \mathrm{cfu} / \mathrm{ml}$ to $10^{3} \mathrm{cfu} / \mathrm{ml}$ after one day of freezing without test materials or with the addition of sodium hexametaphosphate. However, no viable cells were detected when hop resins were added.

Figure 3 shows the viable cell count of $E$. coli after treatment of the nutrient broth containing glycerine. With the standard agar method, the decrease in viable cell count was hardly observed after 8 days of freezing. With the desoxycholate agar method, the viable cell count did not change in the presence or absence of sodium hexametaphosphate, 
1

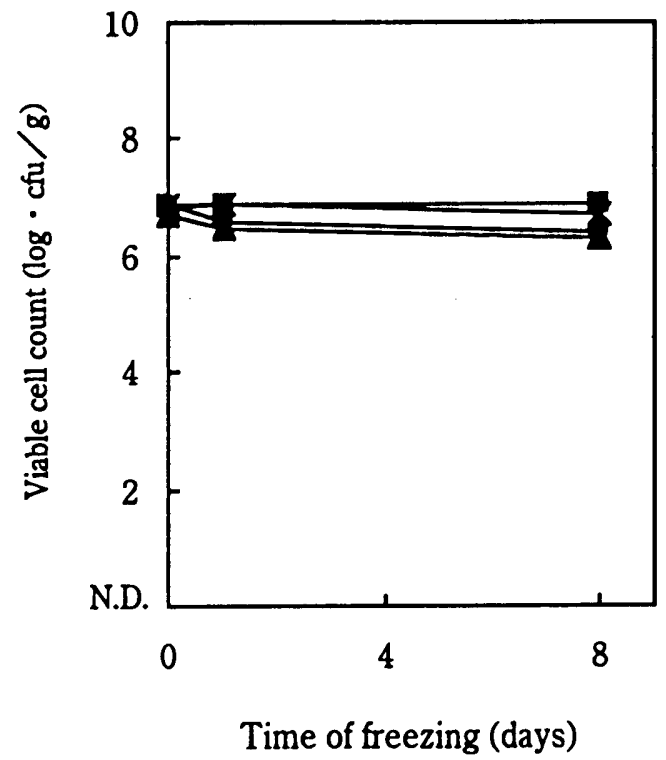

II

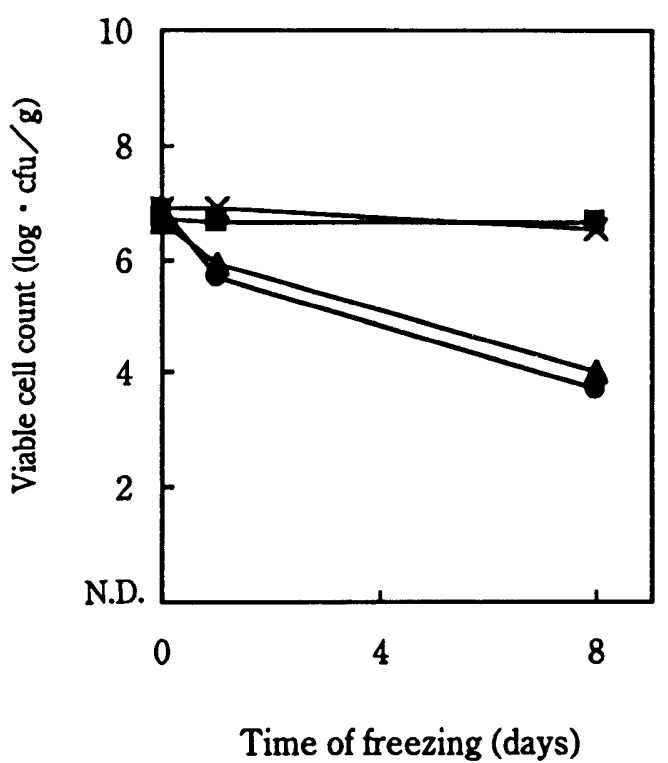

Fig. 3. Viable cell count of $E$. coli after the freeze-thawing treatment in the nutrient broth containing glycerin. The surviving cells were enumerated by the following methods: I. the standard plate count, II. the desoxycholate agar count. Test materials added were as follows. $\times$ : No addition; $\mathbf{\bullet}$ : Hop resins; $\mathbf{\square}$ : Sodium hexametaphosphate; $\Delta$ : Hop resins + Sodium hexametaphosphate.

Table 1. Lag phase time for growth of E. coli when the freeze-thawing treatment was carried out in nutrient broth.

\begin{tabular}{lcc}
\hline \multirow{2}{*}{ Test materials } & \multicolumn{2}{c}{ Lag phase time for growth $(\mathrm{h})$} \\
\cline { 2 - 3 } & Storage for 1 day $\left.^{a}\right)$ & Storage for 8 days $^{a)}$ \\
\hline Control (No test materials) & 12.5 & 15.8 \\
Hop resins & 14.0 & 19.5 \\
Sodium hexametaphosphate & 12.7 & 15.8 \\
Hop resins + Sodium & 16.4 & 25.4 \\
$\quad$ hexametaphosphate & & \\
\hline
\end{tabular}

${ }^{a}$ Storage at $-20^{\circ} \mathrm{C}$.

whereas the viable cell count decreased to $10^{3} \mathrm{cfu} / \mathrm{ml}$ with the addition of hop resins. Consequently, with hop resins (0.01\%), the injury to $E$. coli by the freeze-thawing treatment was promoted, and the freezing-resistance was reduced even in the presence of glycerine, which is a cryoprotective agent against freezing degeneration.

Table 1 shows the lag time for the growth of freeze-treated $E$. coli, grown in nutrient broth. With the addition of hop resins, the lag phase of the $E$. coli was extended by about $4 \mathrm{~h}$. This extension was about 1.2-fold compared to that without addition of a test material. A similar delay in growth was also observed in the nutrient broth containing glycerine (Table 2). That is, the lag phase time was extended about 1.4-fold by adding hop resins. On the other hand, no influence of sodium hexametaphosphate on the lag time was observed. However, the combined use of hop resins and sodium hexametaphosphate caused a synergistic injury action to $E$. coli, followed by extention of the lag phase time by about 1.6-fold.

Neither hop resins nor sodium hexametaphosphate has any antimicrobial activity against $E$. coli (Haas \& Barsoumian, 1994; Tutumi et al, 1976). However, after the freeze-thawing
Table 2. TLag phase time for growth of $E$. coli when the freeze-thawing treatment was carried out in nutrient broth containing glycerin.

\begin{tabular}{lcc}
\hline \multirow{2}{*}{ Test materials } & \multicolumn{2}{c}{ Lag phase time for growth $(\mathrm{h})$} \\
\cline { 2 - 3 } & Storage for 1 day $^{a)}$ & Storage for 8 days $^{a)}$ \\
\hline Control (No test materials) & 6.4 & 6.6 \\
Hop resins & 7.6 & 9.3 \\
Sodium hexametaphosphate & 6.4 & 6.7 \\
Hop resins + Sodium & 7.9 & 10.6 \\
$\quad$ hexametaphosphate & & \\
${ }^{a)}$ Storage at $-20^{\circ} \mathrm{C}$ & &
\end{tabular}

treatment in the presence of these test materials, the viable cell count of $E$. coli was decreased. This effect was especially remarkable in the presence of hop resins. The viable cell count after the thawing was lower with the desoxycholate agar method than that with the standard agar method. This observation was similar to that reported by Speck (1970); Speck \& Cowman (1971). They reported that E. coli which has suffered freeze injury lacked the ability to grow on a medium containing bile salts such as desoxycholate agar. It was considered that the injury was promoted in the presence of hop resins. Generally, most microorganisms undergo freeze injury during freeze-thawing treatments (Ostovar \& Bremier, 1975; Schothorst, 1976; Speck \& Ray, 1977; Warseck, 1973). Kaneda et al. (1985) reported that injury to the outer membrane of $E$. coli was promoted in the presence of sodium hexametaphosphate. The cell membrane became more porous in the presence of sodium hexametaphosphate, followed by the leakage of cell components. Presumably, hop resins may also affect the function of the cell membrane.

Recently, there has been a yearly increase in the consumption of frozen foods. Therefore, hygienic control becomes 
more important. Microorganisms suffer from physiological or metabolic injury by freeze-thawing treatment, and the presence of the hop resins enhances this injury. The microbial viable cell count after thawing decreased greatly, and growth was remarkably retarded. From these findings, it is thought that application of this effect for hygienic control of frozen foods may be possible.

\section{References}

Aitken, R.A., Bruce, A., Harris, J.O. and Seaton, J.C. (1970). The bitterness of hop-derived materials in beer. J. Inst. Brew., 76, 29-36.

Brown, A.J. and Clubb, D. (1913). On the antiseptic properties of hops. J. Inst. Brew., 19, 261-295.

Chapman, A.C. (1929). On the preservative properties of hops. J. Inst. Brew., 31, 13-31.

Chin, C.Y., Chang, N.C. and Anderson, H.H. (1949). Factors influencing the antibiotic activity of lupulon. J. Clin. Invest., 28, 909-915.

Erdmann, W.F. (1951). Lupulon und humulon, ihre antibakterielle wirksamkeit und anwendung bei tuberkulosen infektionen. Pharmazie, 6, 442-451.

Haas, G.J. and Barsoumian, R. (1994). Antimicrobial activity of hop resins. J. Food Prot., 57, 59-61.

Hough, J.S., Howard, G.A. and Slater, C.A. (1957). Bacteriostatic activities of hop resin materials. J. Inst. Brew., 63, 331-333.

Jaehrig, A. and Schade, W. (1981). Untersuchungen zur antimikrobiellen wirksamkeit von hopfeninhaltsstoffen und deren umwandlungsprodukten gegenueber mikroorganismen in der brauerei. Lebensmittelindustrie, 28, 311-315.

Kaneda, H., Watanabe, T. and Tsutsumi, M. (1985). Sites of injury in Escherichia coli induced by freezing in the presence of hexametaphosphate or cholate. J. Food Hyg., Soc. Jpn., 26, 144-149.

Kleyn, J. and Hough, J. (1971). The microbiology of brewing. Ann. Rev. Microbiol, 25, 583-608.

Kuroiwa, Y., Kokubo, E. and Hashimoto, N. (1972). Advanced hop chemistry in connection with beer flavour. In "Fermentation Technology Today, "ed. by G. Terui. Society of Fermentation Technology, Osaka, pp. 633-637.

Laws, D.R.J. and McGuinness, J.D. (1972). Origin and estimation of the gushing potential of isomerized hop extracts. J. Inst. Brew., 78, 302-308.

Macrae, R.M. (1964). Significance of the use of hop in regard to the biological stability of beer. J. Inst. Brew., 70, 340-344.

Michener, H.D., Snell, N. and Lansen, E.J. (1948). Antifungal activity of hop resin constituents and a new method for isolation of lupulon.
Arch. Biochem., 19, 199-208.

Mizobuchi, S. and Sato, Y. (1984). A new flavanone with antifungal activity isolated from hops. Agric. Biol. Chem., 48, 2771-2775.

Mizobuchi, S. and Sato, Y. (1985). Antifungal activities of hop bitter resins and related compounds. Agric. Biol. Chem., 49, 399-403.

Schmalreck, A.F., Teuber, M., Reininger, W. and Hartl, A. (1975). Structural features determining the antibiotic potencies of natural and synthetic hop bitter resins, their precursors and derivatives. Can. J. Microbiol., 21, 205-212.

Schothorst, M. (1976). Resuscitation of injured bacteria in food. In "Inhibition and Inactivation of Vegetative Microbes," ed. by F.A. Skinner and W.B. Hugo. Academic Press, London, pp. 317-328.

Ostovar, K. and Bremier, M.J. (1975). Effect of thawing on growth of Staphylococcus aureus in frozen convenience food items. J. Milk Food Technol., 38, 337-339.

Shimwell, J.L. (1937). On the relation between the staining properties of bacteria and their reaction towards hop antiseptic. Part I. J. Inst. Brew., 43, 111-118.

Simpson, W.J. (1993). Studies on the sensitivity of lactic acid bacteria to hop bitter acids. J. Inst. Brew., 99, 405-411.

Simpson, W.J. and Smith, A.R.W. (1992). Factors affecting antibacterial activity of hop compounds and their derivatives. J. Appl. Bacteriol., 72, 327-334.

Smith, N.A. and Smith, P. (1993). Antibacterial activity of hop bitter resins derived from recovered hopped wort. J. Inst. Brew., 99, 43-48.

Speck, M.L. (1970). Selective culture of spoilage and indicator organisms. J. Milk Food Technol., 33, 163-167.

Speck, M.L. and Cowman, R.A. (1971). Symposium on the restoration of sublethally impaired bacterial cells in foods, 2 injury and recovery of frozen microorganisms. J. Milk Food Technol., 34, 548-552.

Speck, M.L. and Ray, B. (1977). Effects of freezing and storage on microorganisms in frozen foods. J. Food Protect., 40, 333-336.

Teuber, M. and Schmalreck, F. (1973). Membrane leakage in Bacillus subtilis 168 induced by the hop constituents lupulone, humulone, isohumulone and humulinic acid. Arch. Mikrobiol., 94, 159-171.

Tutumi, M., Nishimura, K., Yasui, K., Matuoka, A. and Watanabe., T. (1976). Synergistic action of cholate on some antimicrobial substances. J. Food Hyg. Soc. Jpn., 17, 273-275.

Verzele, M. (1972). Hop extracts, chemistry analysis and utilization. European Brewery Convention. Proc. 13th Congr., Estoril 1971. North Holland Publ. Co., Amsterdam, London. pp. 95-106.

Walker, T.K. and Blakebrough, N. (1952). Bacteriostatic power of humulone boiling product. J. Inst. Brew., 58, 13-21.

Walker, T.K. and Parker, A. (1937). Report on the preservative principles of hops. Part XVIII. J. Inst. Brew., 43, 17-30.

Warseck, M. (1973). Repair and enumeration of injured coliforms in frozen foods. Appl. Microbiol., 26, 919-924. 